\title{
STUDI LITERATUR : PERAN STRATIFIKASI SOSIAL MASYARAKAT DALAM PEMBENTUKAN POLA PERMUKIMAN
}

\author{
Boby Rahman ${ }^{1)}$, Ega Selviyanti ${ }^{2)}$ \\ Program Studi Perencanaan Wilayah dan Kota Universitas Islam Sultan Agung Semarang ${ }^{1), 2)}$ \\ Email Korespondensi : bobyrahman@unissula.ac.id
}

\begin{abstract}
Socio and cultural system which believed as the result of relationship, communication, individual socialization in society has an effect on the form of the society's environmental order. The effect of relationship, communication and socialization which created a social system of society that makes the society divided into layers or positions based on believes values, norms and customs in society. This study uses literature study in reviewing the effect of social stratification with taking case study in Solo, Bali and Madura. The result of this study can be concluded that social stratification has a role in the formation of society settlements. That social stratification then forms a society environmental order in both spatial and physical architecture of buildings.
\end{abstract}

Keywords: social stratification, settlements formation, settlement pattern

\begin{abstract}
ABSTRAK
Sistem sosial dan budaya yang dipercayai sebagai hasil hubungan,komunikasi, sosialisasi individu dalam masyarakat mempunyai pengaruh atas bentuk tatanan lingkungan masyarakat. Akibat dari hubungan, komunikasi dan sosialisasi dalam masyarakat sehingga terciptalah sistem sosial masyarakat yang menjadikan masyarakat terbagi dalam lapisan-lapisan atau kedudukan berdasarkan kepercayaan, nilai, norma dan adat istiadat dalam masyarakat. Penelitian ini menggunakan pendekatan studi literature dalam mengkaji pengaruh stratifikasi sosial, dengan mengambil studi kasus di Solo, Bali dan Madura. Hasil dari kajian ini dapat disimpulkan bahwa stratifikasi sosial mempunyai peran pembentukan permukiman masyarakat. Stratifikasi sosial tersebut kemudian membentuk tatanan lingkungan pola lapisan permukiman masyarakat baik yang bersifat spatial maupun fisik arsitektur bangunan..
\end{abstract}

Kata Kunci: Stratifikasi Sosial, Pembentukan Permukiman, Pola Permukiman 
Jurnal Planologi Vol. 15, No. 2, Oktober 2018

Available : http://jurnal.unissula.ac.id/index.php/psa

\section{PENDAHULUAN}

Lingkungan permukiman pada suatu wilayah secara universal terbentuk karena berbagai unsur, diantaranya adalah budaya masyarakat. Budaya atau kebudayaan masyarakat adalah keseluruhan sistem gagasan dan rasa, tindakan serta karya yang dihasilkan oleh manusia sebagai anggota masyarakat dalam kehidupan bermasyarakat, yang kemudian secara alami menjadikan identitasnya melalui proses belajar (Koentjaraningrat, 1992). Dasar budaya dalam masyarakat terbentuk dengan adanya komunikasi yang secara fisik dapat terlihat sebagai hasil dari aktifitas manusia yang dikenal sebagai pola tata ruang budaya (Rapoport, 1980) yaitu sebuah karya yang menggambarkan secara visual terhadap perilaku, serta symbol dan nilai yang muncul dari suatu kelompok masyarakat tertentu. Bentuk fisik dan nilai yang merupakan hasil dari budaya yang terbentuk melalui sejarah panjang yang terjadi secara turun temurun dari beberapa generasi disebut sebagai warisan budaya (Karmadi, 2007). Warisan budaya berupa nilai, adat istiadat dan tradisi pada suatu daerah tertentu membentuk kultural spesifik yang berisi suatu karakter yang khas. Tradisi ini memiliki pengaruh dominan terhadap keputusan yang kemudian mempengaruhi permukiman masyarakat itu sendiri.

Permukiman merupakan salah satu hasil yang terbentuk dari eksistensi sistem dan tata nilai yang dijalankan oleh masyarakat dalam kehidupan. Suatu permukiman masyarakat dapat terbentuk akibat pengelompokan profesi, ekonomi, hak dan kewajiban (Aliya, 2004) yang menjadi produk komunitas dan terbentuk secara alami dan berbeda satu dengan lainnya. Dalam permukiman terdapat istilah konsep konstektual yang selaras untuk bertempat tinggal, dari konsep inilah muncul keinginan untuk tinggal dan menetap bersama dengan orang-orang sehingga membentuk unsur fisik spasial (berupa lokasi sebagai tempat tinggal) dan unsur non fisik (berupa kegiatan bermasyarakat yang membentuk kebiasaan dan adat istiadat masyarakat) dalam suatu wilayah yang di dalamnya terdapat tata kehidupan sosial budaya. Implikasinya, banyak permukiman yang terpengaruh oleh nilai dan perilaku budaya dalam kehidupan bermasyarakat sehingga membentuk lokasi tertentu dan menjadi wujud ruang yang membentuk pola permukiman yang identik dengan sosial budaya masyarakat itu sendiri.

Permukiman dalam masyarakat senantiasa tersusun secara alami oleh masyarakat penghuninya berdasarkan kebudayaan masyarakat yang bersangkutan. Hal ini menyiratkan bahwa permukiman merupakan salah satu buah hasil dari kebudayaan yang tersusun atas nilai, tradisi termasuk sistem strata sosial yang menjadi bagian dari kebudayaan itu sendiri. 
Sehingga budaya memberikan pengaruh yang khas terhapa terbentuknya suatu permukiman, maka pada studi ini akan membahasStudi Literatur terkait pengaruh stratifikasi sosial masyarakat terhadap pola permukiman kota,berdasarkan analisis hasil kajian-kajian studi-studi literatur yang telah dilakukan. Pada studi ini akan dibahas dan dikaitkan dengan berbagai studi kasus yang terkait dengan pengaruh sosial budaya masyarakat terhadap pola permukiman kota. Sasaran yang dilakukan untuk mencapai tujuan tersebut ialah mengidentifikasi elemen pembentuk stratifikasi sosial sebagai salah satu warisan budaya, mengidentifikasi elemen stratifikasi sosial sebagai pembentuk permukiman masyarakat dan mengkaji bentuk pola permukiman masyarakat yang terbentuk akibat stratifikasi sosial sebagai warisan budaya.

\section{METODOLOGI}

Metodologi yang digunakan dalam penelitian ini adalah metodologi kualitatif, dengan pendekatan teknik analisis studi literatur. Studi literatur bertujuan untuk mendukung dan meningkatkan pemahaman terhadap sebuah objek penelitian (Pusparinda dan Santoso, 2016). Pada Studi literaturpara peneliti akan melakukan pendalaman yang lebih luas dan mendalam terhadap masalah yang hendak diteliti (Kartiningrum, 2015). Menurut Danial dan Warsiah (2009) Studi Literatur adalah merupakan penelitian yang dilakukan oleh peneliti dengan mengumpulkan sejumlah buku buku, majalah yang berkaitan dengan masalah dan tujuan penelitian. Teknik ini dilakukan dengan tujuan untuk mengungkapkan berbagai teori-teori yang relevan dengan permasalahan yang sedang dihadapi/diteliti sebagai bahan rujukan dalam pembahasan hasil penelitian.

Studi literature utama yang diambil dalam penelitian ini ada kajian studi yang berada di Kota Solo, Bali dan Madura. Alasan pemilihan ketiga lokasi studi tersebut dikarena kota Solo mewakili permukiman dengan stratifikasi jawa, Bali mewakili permukiman dengan stratifikasi Hindu dan Madura mewakili permukiman dengan strafikasi muslim. Ketiga kategori tersebut (jawa, hindu, muslim) merupakan aspek sosial yang sangat kental dan dominan secara historis maupun pada kehidupan masyarakat Indonesia.

\section{HASIL DAN PEMBAHASAN}

Sub bab ini akan menjelaskan mengenai pengaruh stratifikasi sosial terhadap pola permukiman masyarakat yang ditinjauh dari studi kasus permasalahan yang telah dikaji sebelumnya. Adapaun studi kasus yang dikaji yaitu pengaruh stratifikasi sosial terhadap pola permukiman dengan studi kasus : Madura, Kota Kerjaan Surakarta dan Bali. Ketiga lokasi tersebut merupakan beberapa daerah dengan bentuk pola permukiman yang 
dipengaruhi stratifikasi sosial atau lapisan sosial dalam masyarakat. Sehingga dari studi kasus tersebut akan dijelaskan apa elemen pembentuk stratifikasi sosial dalam masyarakat, stratifikasi sosial yang mempengaruhi pola permukiman hingga bentuk pola permukiman yang dipengaruhi oleh stratifikasi sosial itu sendiri.

\section{A. Konsep Mancapat-Mancalima Dalam Struktur Kota Kerajaan Mataram Islam Periode Kerajaan Pajang sampai dengan Surakarta}

Kerajaan Mataram Islam, berdiri setelah kerjaan Demak berakhir. Seiring dengan pergantian penguasa, menyebabkan pusat kerajaan yang terus berpindah-pindah. Perpindahan pusat kerjaan masih menunjukan unsu-unsur kerajaan Jawa pada umumnya berupa Keraton, Alun-alun, Masjid, Pasar, rumah-rumah bangsawan dan permukiman abdi dalem. Susunan elemen-elemen kota kerajaan tersebut didasarkan pada keyakinan kosmologi Jawa yang bersumber dari kepercayaan Hindu-Budha. Kepercayaan akan raja sebagai dewa mencipatakan corak-corak sakral pada struktur kota kerajaan dengan puncak kekuasaan adalah raja.

Pemahaman masyarakat Jawa tradisonal tentang kota ialah suatu lingkungan berpagar atau tembok yang didalam lingkungan tersebut merupakan tempat tinggal pemimpin, para pejawab dan pegawai kerajaan yang disebut sebagai kutha. Namun, seiring perjalannan waktu terjadu perubahan akan makna kutha yaitu sebuah lingkungan tidak lagi harus ditutupi oleh pagar atau tembok tertentu. Penggambaran sebuah kota juga dapat dilihat dari morfologi dan bentuk fisik yang berlatar belakang budaya-sosial masyarakat. Pada kasus kota Surakarta misalnya, kerajaan Surakarta yang berdiri saat pemerintahan Hindia Belanda sehingga tumbuh dan berkembang dengan aneka budaya. Konsep mancapat-mancalima dalam struktur ruang kerajaan Mataram Islam, dapat dilihat dari latar belakang budayanya (Murtoyoso, 1993). Sehingga pembentukan struktur kota pada kota Surakarta sangat dipengaruhi oleh bentuk kerajaan Mataram Islam.

\section{Elemen Stratifikasi Sosial sebagai bagian dari warisan budaya}

Pada masa kota kerajaan Mataram Islam periode kerajaan Pajang sampai dengan Surakarta. Ruang tersebut terbagi menjadi dua ruang yaitu ruang profan dan ruang sakral yang didalamnya juga terdapat garis-garis imajiner yang memisahkan setiap ruang sebagai salah satu bentuk perwujudan lapisan sosial. Berikut adalah gambaran garis-garis imajiner yang terdapat pada masa kerajaan Mataram Islam menurut Santoso (1984): 


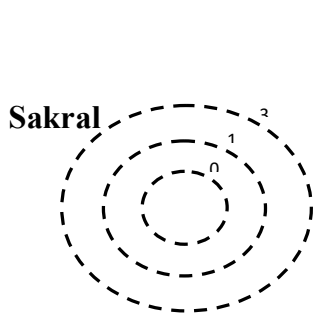

(a)

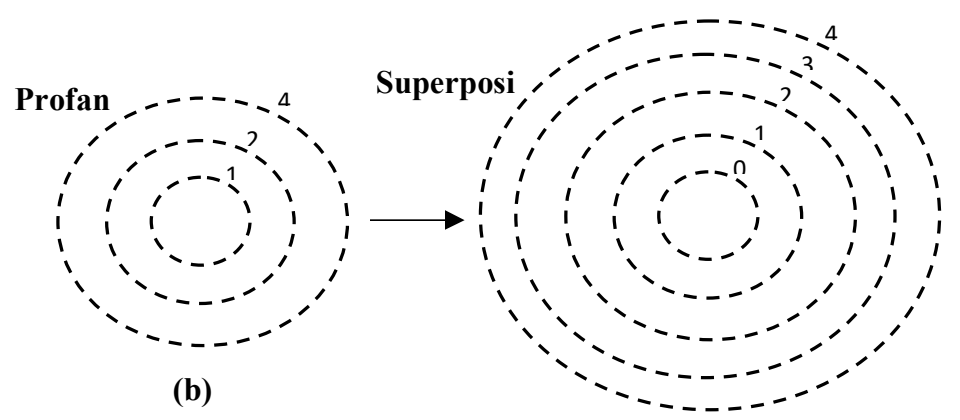

Gambar 1. Lingkaran Tata Ruang Negara Mataram (c) Sumber : Santoso, 1984

Lingkaran ruang sakral dalam sistem hirarki kerajaan Mataram Islam merupakan pusat sisitem yang secara simbolik sebagai satu-satunya pusat bagi negara. Ruang sakral kerajaan Mataram Islam pada gambar (a) adalah lingkaran pusat dalem yang menjadi tempat tinggal raja dan negara agung, yaitu sebuah ruang yang tidak dapat dimasuki oleh semua orang. Hanya masyarakat dengan tingkatan sosial tertentu seperti keluarga raja, pejabat tinggi keraton dan abdi dalem kerajaan yang bekerja pada bidang tertentu serta pada lingkar imajiner ketiga yang merupakan negara agung atau tanah yang suci yaitu tanah yang menjadi hak paten kepemilikan berada pada kerajaan dan merupakan tanah dengan status hak guna pakai.

Lingkaran ruang profan pada sistem kerajaan Mataram Islam terdiri atas tiga garis imajiner yang dianggap lebih duniawi. Lingkaran ruang profane ini meliputilingkaran batas keraton, lingkaran batas negara atau birokrasi kerajaan dan lingkaran mancanegara yang merupakan lingkaran ruang diluar negara. Pada ruang profan raja dan keluarga raja, pejabat tinggi keraton, maupun abdi dalem dapat memasuki ruang tersebut. Sehingga dapat dilihat secara jelas bahwa pada ruang sakral tidak dapat dimasuki oleh semua orang sedangkan ruang profane dapat digunakan oleh semua orang dari berbagai tingkatan lapisan masyarakat.

\section{Stratifikasi Sosial sebagai warisan budaya yang membentuk Pola Permukiman}

Masyarakat Jawa pada umumnya masih meyakini keraton sebagai pusat dan merupajan tempat tinggal Raja dan menjadikan sebagai kiblat dalam tata hidup dan tata nilai serta tata permukiman masyarakat. Tata permukiman masyarakat Jawa terdapat hirarki ruang sebagai manifestasi dari kedudukannya atau tingkatannya dalam masyarakat, misalnya keraton sebagai tempat tinggal raja menjadi pusat permukiman dengan tingkat tertinggi dan ruang-ruang lainnya membentuk lingkaran secara imajiner (melingkar mengikuti pusat) secara bertingkat sejalan dengan status dalam masyarakat. Semakin rendah status dalam masyarakat maka bertempat semakin luar dalam lingkar imajiner 
(semakin jauh dari pusat) (Junianto, 2016). Perjalanan panjang sejarah kerjaan Matarm Islam yang dimulai dengan berdirinya keraon Pajang di sebelah barat Surakarta, berpindah ke Kotagede hingga berpindah di Kartasura sistem kehidupan masyarakt menjadi berubah. Masyarakat yang semula dipimpin oleh seorang Kiai, berubah menjadi kerakaan dengan susunan hirarki dimana raja sebagai puncak tertinggi, diikuti lapisan bangsawan, abdi dalem, pengiring dan para abdi. Berdasarkan penelitian dari Junianto (2016), maka didapat tata pola permukiman kerajaan Pajang sampai dengan Surakarta:

\section{a. Kerajaan Pajang}

Kerajaan Pajang terletak pada sebelah barat wilayah kota Surakarta sekarang. Keraton pajang sebagai pusat tatanan kota Kerajaan dikelilingi oleh tembok sebagai pembatas ruang. Keraton Pajang sebagai ruang yang bersifat sakral meliputi istana kerajaan sebagai kediaman raja dan alun-alun. Disebelah kanan istana terdapat bangunan rumah tinggal pangawal istana dan serdau. Tatanan ini menunjukan areal yang bersifat profan dan sakral. Tumenggung sebagai pimpinan pemerintahan atas anama raja, berada pada sebelah barat keraton. Tempat tinggal putra mahkota berlokasi di depan pasar. Unsurunsur lain seperti kepatihan,pasar, pos pengawas pasar terletak disebelah alun-alun utara.

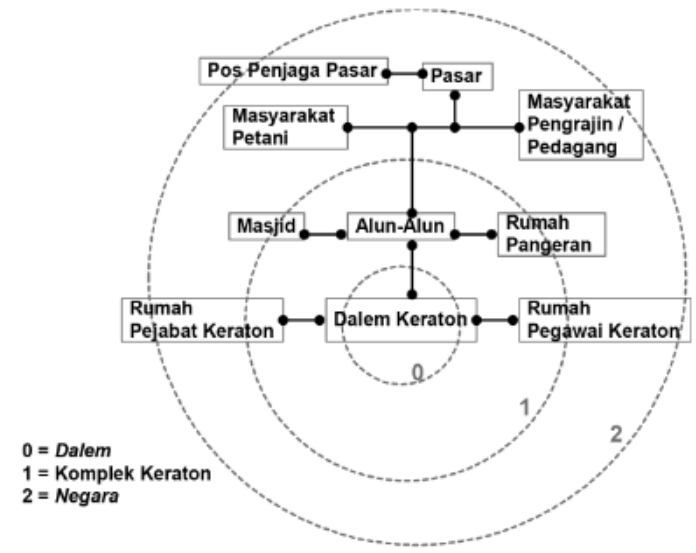

Gambar 2. Lingkaran Tata Ruang Kota Kerajaan Pajang Sumber : Junianto 2016

\section{b. Kerajaan Plered}

Kerajaan Plered terletak sekitar $57 \mathrm{~km}$ sebelah timur Yogyakarta. Kerajaan Plered dikelelilingi oleh tembok pagar kota dengan ketinggian 6-7 meter. Didalam tembok keraton terdapat istana raja dan rumah para pangerah yang terdapat pada sepanjang jalan pintu gerbang menuju istana kerajaan sebagai kediaman raja. Selain itu juga terdapat bangsal kencana, rumah jaga Gedong Kemuning, masjid keraton Suranata, Gedong 
kedondong dan sumur Guleng tempat memandikan keris. Disebelah utara kompleks keraton terdapat alun-alun berukuran 300 x 400 meter dengan masjid disebelah baratnya dan di dalam komplek masjid terdapat makam.

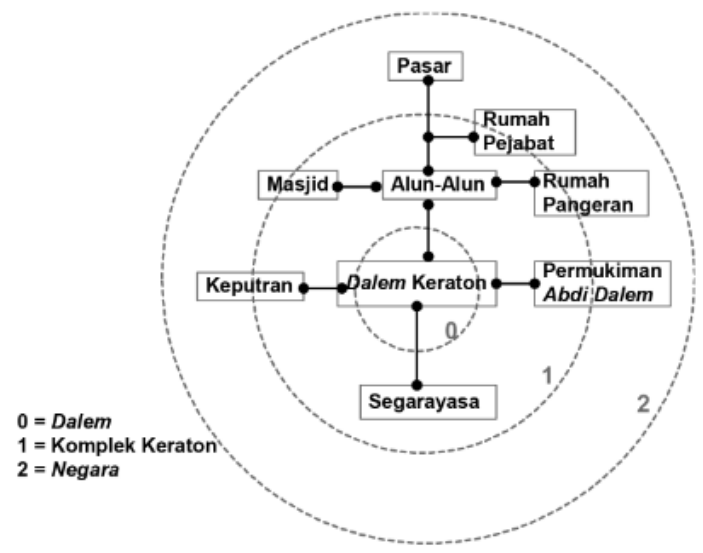

Gambar 3. Lingkaran Tata Ruang Kota Kerajaan Plered Sumber : Junianto 2016

\section{c. Kerajaan Kartasura}

Sama dengan kerajaan sebelumnya, pusat kegiatan kerajaan Kartasura juga berada pada sekitar Keraton. Kerajaan Karasura terletak dibagian barat luar kota Surakarta yang sekarang. Pada masa kerajaan Kartasura pihak-pihak asing seperti Belanda, Cina dan Arab mulai masuk dan mempengaruhi kerajaan. Pihak asing mulai membangun perkampungan masing-masing meskipun yang paling mempengaruhi Kartasura adalah Belanda. Pada masa kerajaan Kartasura terdapat alunalun selatan sebagai pengganti Segarayasa (laut buatan). Segarayasa memiliki makna simbolis berupa sumber kehidupan dan bersifat profane. Alunalun utara yang menyatu dengan masjid dianggap sebagai ruang sakral. Keraton memiliki dua orientasi, yaitu ruang yang bersifat sakral dan profan. Sebelah utara keraton lebih bersifat sakral dan sebelah selatan bersifat profan. Pada masa kerajaan Kartasura, tembok sebagai pembatas antar ruang sakral dan ruang profane serta sebagai garis jelas dari status dalam masyarakat kota kerajaan semakin Nampak. 


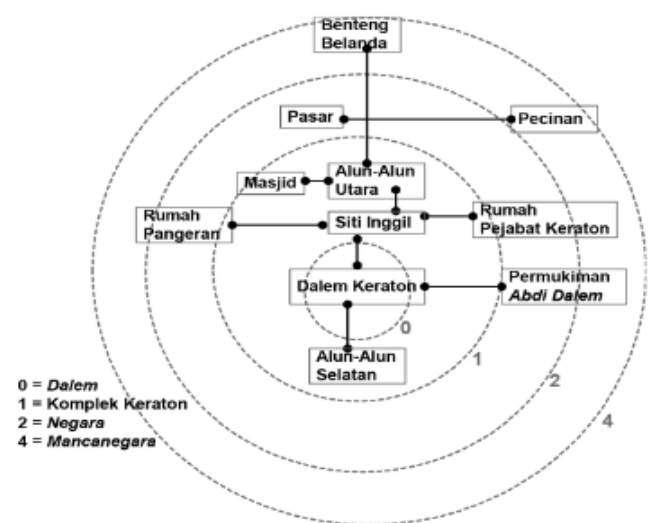

Gambar 4. Lingkaran Tata Ruang Kota Kerajaan Kartasura Sumber : Junianto 2016

\section{d. Kerajaan Surakarta}

Seperti Kartasura, Kerajaan Suakarta juga memiliki dua alun-alun yaitu alunalun utara dan alunalun selatan yang masing-masing ditanamai dua buah pohon beringin pada pertengahan alunalun dan komplek keraton berada diantara dua aunalun tersebut. Pada bagian dalem keraton dipisahkan oleh tembok setinggi 3 meter dengan tembok keraton yang ke dua (benteng). Di dalam benteng terdapat keraton, dalem terpisah dengan bangunan keraton lainnya. Diantara tembok keraton yang pertama dan kedua terdapat hunian para pangeran yang bertugas dalam pemerintahan da $a b d i$ dalem.

Komplek keraton beserta alun-alun menunjukan ciribagian kota yang sakral. Permukiman orang asing yang beragama lain dan daerah eksteritorial seperti Mangkunegara dan 'kota Eropa' terdapat pada sebelah utara. Sehingga, daerah alunalun Utara dianggap bersifat profane sedangkan daerah sebelah selatan bersifat sakral.

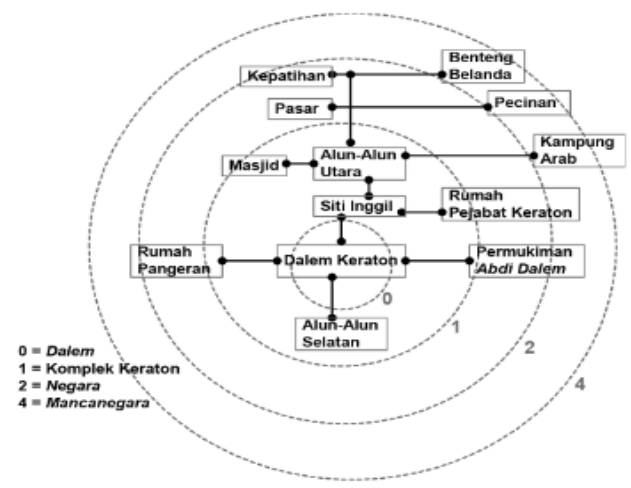

Gambar 5. Lingkaran Tata Ruang Kota Kerajaan Surakarta Sumber : Junianto 2016 


\section{B. Pengaruh Sistem Catur Wangsa terhadap Perwujudan Tata Spatial Kota Peninggalan Kerajaan Hindu Di Bali: Kasus Kota Karangasem}

Kota Karangasem merupakan salah satu kota peninggalan kerajaan Karangasem di bali yang memiliki karakteristik spatial kota dan kehidupan masyarakat yang khas. Hal ini dipengaruhi oleh sistem sosial masyarakat yang terbagi menjadi beberapa golongan yaitu catur wangsa (kelompok sosial) yang selanjutnya mempengaruhi penampakan kota Karangasem secara fisik spatial.

\section{Elemen Stratifikasi Sosial sebagai bagian dari warisan budaya}

Kot Karangasem merupakan salah satu kota lama peninggalan kerajaan Hindu di Bali yang masyarakatnya telah terbagi menjadi beberapa golongan dengan strata sosialnya. Pembagian golongan atau kelompok tersebut didasarkan pada jenis pekerjaan, garis keturunan da nasal masyarakatnya. Pembagian golongan masyarakat tersebut salah satunya adalah catur wangsa.

Sistem catur wangsa mengelompokan masyarakat menjadi empat golongan berdasarkan garis keturunan dan starata sosialnya dalam masyarakat yang dipengaruhi oleh masuknya agama Hindu di Bali. Selain catur wangsa, masyarakat Bali juga mengenal catur warna dalam pengelompokan masyarakat. Catur warna terdiri dari dua kata yaitu, catur adalah empat dan warna atau vri yaitu memilih pekerjaan. Sehingga catur warna diartikan sebagai sistem pembagian masyarakat kedalam empat golongan berdasarkan konsep dharma atau swadharma, yaitu sesuai dengan kewajiban, bakat atau jenis pekerjaan.

Sedangkan catur wangsa atau catur jatma dipahami sebagai pembagian masyarakat menjadi empat kelompok berdasarkan jati (lahir), yaitu sesuai dengan garis keturunan atau kelahiran yang pada akhirnya menciptakan masyarakat dengan sistem kasta yang terkait dengan keturunan atau ras tertentu. Sistem Catur Wangsa, meliputi Triwangsa dan Non Triwangsa. Triwangsa terbagi menjadi Brahmana, Ksatrya dan Wesya, sedangkan Non Triwangsa turun menjadi sudra.

Brahmana adalah golongan rohaniawan dan cendekiawan yang berkewajiban mengembangkan ilmu pengetahuan dan turunannya. Golongan kedua adalah ksatrya yang merupakan golongan pemimpim yang memiliki kewajiban dalam menjalankan pemerintahan dan militer serta turunan dari kedua hal tersebut. Wesya adalah golongan ketiga berupa golongan pedagang yang memiliki wewenang dalam perdagangan dan bertanggung jawab atas kesejahteraan masyarakat dan golongan terakhir adalah sudra yang merupakan kelompok masyarakat dengan golongan terendah sebagai pekerja. 


\section{Stratifikasi Sosial sebagai warisan budaya yang membentuk Pola Permukiman}

Berdasarkan pemabahasan sebelumnya telah dijelaskan bahwa masyarakat Bali membagi masyarakatnya ke dalam 4 kelompok masyarakat yang disebut sebagai catur wangsa. Catur wangsa terdiri atas kelompok brahmana, kstarya, wesya dan sudra. Tiap kelompok masyarakat tersebut kemudian memiliki bentuk hunian yang khusus sesuai dengan fungsi dan kedudukannya dalam masyarakat. Kelompok brahmana sebagai kelompok masyarakat tingkat pertama memiliki hunian yang disebut geria. Puri adalah isana bagi raja dan keluarganya yang merupakan golongan ksatria sedangkan punggawa atau masyarakat dengan darah biru (bangsawan) yang tidak memegang kekuasaan dan keluarganya tinggal dalam hunian yang disebut jero. Umah atau rumah adalah hunian bagi golongan sudra.

Masing-masing hunian tersebut juga terbagi atas kelompok-kelompok ruang dengan pembedaan ruang sakral dan ruang profan yang juga diartikan sebagai tingkat kesucian setiap ruang.

(a) puri memiliki nilai utama yaitu ruang dengan tingkat yang paling suci atau sakral. Sebagai ruang yang memiliki tingkat utama, puri memiliki pekarangan yang luas dan terletak pada penempatan agung yang dianggap sebagai simpang sakral dan pusat dunia, sehingga menjadi pusat kota Karangasem. Dalam wilayah Kota Karangasem, terdapat empat puri yang terletak di sekitar areal catuspatha, yaitu (1) Puri Amlaraja atau Puri Kelodan di sebelah kaja kauh (barat laut) catuspatha; (2) Puri Gede Karangasem di sebelah kaja (utara) Puri Kelodan; (3) Puri Agung Karangasem atau Puri Kanginan di sebelah kaja kangin (timur laut) catuspatha; dan (4) Puri Kaleran di sebelah kaja (utara) Puri Gede Karangasem. Hal ini memperlihatkan bahwa seluruh puri di Kota Karangasem terletak di sebelah kaja (utara) catuspatha yang merupakan areal hulu, dan terletak di areal pusat kota sebagai areal utama Kota Karangasem.

(b) geria dan jero bernilai madya yaitu ruang yangberada diantara suci dan nista. Jero sebagai hunian bagi penggawa atau bangsawan yang tidak memegang kekuasaan jero terletak pada sekitar areal puri karena merupakan perluasan dari puri karena masih dalam bagian keluarga raja. Dalam wilayah Kota Karangasem, terdapat tujuh jero di sekitar kawasan puri, yaitu (1)Jero Kaler Kauh; (2) Jero Pekudaan; (3) Jero Taman; (4) Jero Kawan; (5) Jero Jagaraga; (6) Jero Kelodan Pesagi; dan (7) Jero Kelodan Celuknegara. Geria merupakan hunian brahmana dengan pekarangan yang lebih kecil dibandingkan dengan puri dan terletak pada sekitar kawasan puri hal ini dikarenakan 
pada zaman dulu brahmanan bertugas sebagai penasehat raja dan penanggung jawab berbagai ritual keagamaan. Geria yang terdapat pada kota Karangasem antara lain (1) Geria Pendem; (2) Geria Pidada; (3) Geria Karang Sidemen; (4) Geria Cawu; (5) Geria Punia; (6) Geria Tegeh; (7) Geria Sindhu; dan (8) Geria Gerembeng. Berikut adalah tatanan lokasi puri, geria dan jero pada Kota Karangasem:

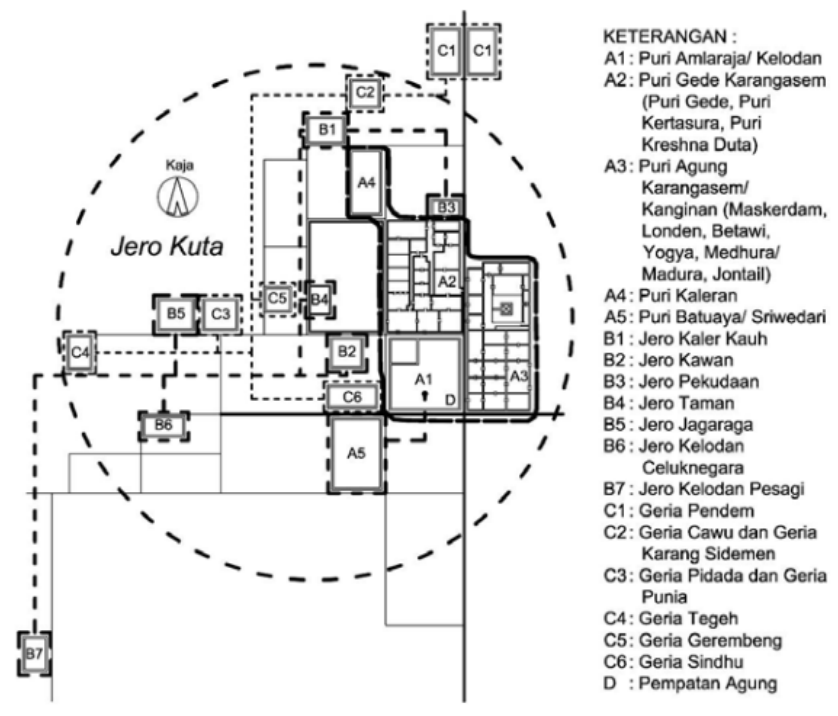

Gambar 6. Tata Letak Puri, Jerod dan Geria

Sumber : Hardy, dkk 2015

(3) umah bernilai nista yaitu ruang yang berada paling luar dan bernilai tidak suci yang terletak pada pinggiran atau luar kota. Hunian masyarakat tersebut juga membentuk kelompok-kelompok hunian sendiri, yaitu hunian yang berbentuk umah-banjarr pakraman untuk masyarakt kelompok sudra dan rumah kampong untuk masyarakat dengan golongan yang berada diluar golongan tersebut (pendatang) terutama yang berasal dari Lombok dan Jawa membentuk hunian.

Berdasarkan penjelasan dapat diketahui bahwa terdapat kesesuaian konsep trimandala dalam konsep hunian triwangsa yang kemudian membagi kota Karangasem menjadi 3 mandala berdasarkan hirarkinya, yaitu:

1. Utama mandala

Merupakan wilayah pusat kota yang ditandai dengan keberadaan puri sebagai hunian dengan nilai utama.

\section{Madya mandala}

Ialah wilayah sekitar pusat kota yang ditandai dengan keberadaan jero dan geria sebagai hunian dengan nilai madya atau tengah. 


\section{Nista mandala}

Merupakan wilayah yang berada pada pinggiran kota yang ditandai dengan keberadaan umah-banjar pakraman dan rumah-kampung.

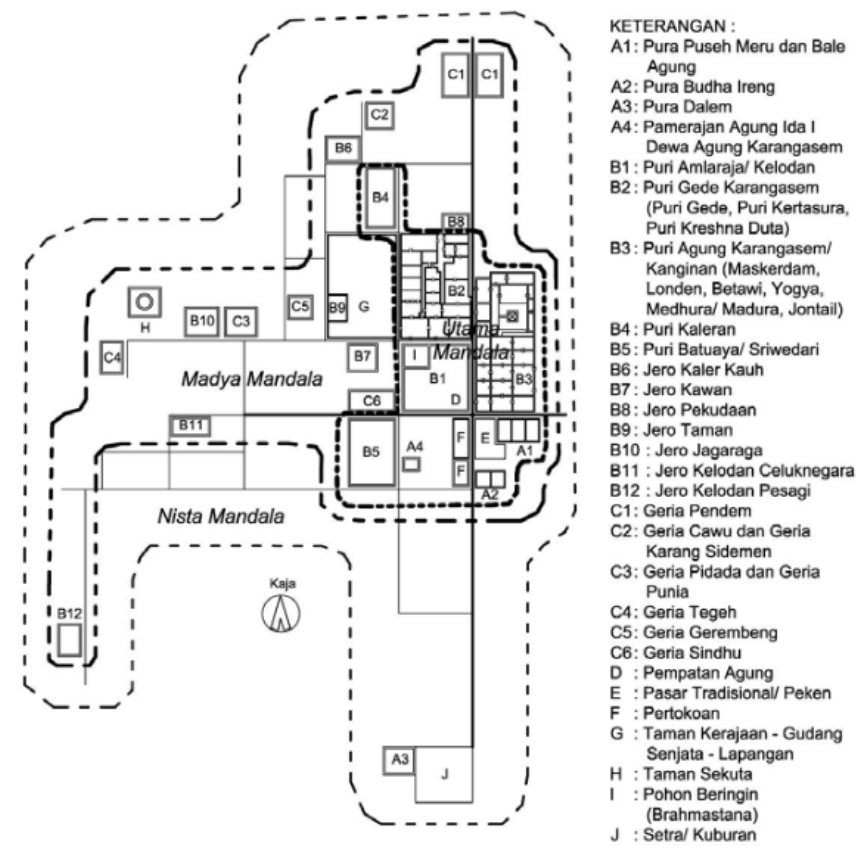

Gambar 7. Tata Hunian Masyarakat Karangasem berdasarkan Trimandala

Sumber : Hardy, dkk 2015

Berdasarkan penjelasan tersebut dapat disimpulkan bahwa sistem catur wangsa memiliki pengaruh terhadap perwujudan tata spatian Kota Karangasem. Statifikasi sosial masyarakat dimanifestasikan kedalam ketiga lapisan ruang yang menunjukan ruang utama, madya dan nista.

\section{Kajian Desain Lanskap Permukiman Tradisional Madura}

Masyarakat Madura termasuk dalam masyarakat yang menganut hubungan hubungan kekerabatan yang memperhitungkan atau mengikuti garis keturunan laki-laki dan perempuan secara sama dan setara sehingga tidak ada perbedaan antara keluarga lakilaki dan perempuan (Rifa'i, 2007). Namun, keterkaitan dalam keluarga sangat besar, hal ini dapat terlihat dalam penataan permukiman masyarakat Madura.

Masyarakat Madura yang penduduknya mayoritas memeluk agama Islam menjadikan pola sika dan perilaku masyarakat Madura didasarkan pada keyakinan kepada Allah sebagai Tuhan Yang Maha Esa. Selain itu sistem stratifikasi sosial, harga diri yang melekat kuat serta sistem kekerabatan yang menjadi dasar dan landasan perilaku masyarakat Madura (Wiyata, 2002). 


\section{Elemen Stratifikasi Sosial sebagai bagian dari warisan budaya}

Secara garis besar pelapisan sosial meliputi tiga lapisan yaitu oreng kene sebagai lapisan terbawah, ponggaba sebagai lapisan menengah, dan parjaji sebagai lapisan paling atas (wiyata 2002). Oreng kene atau orang kecil adalah kelompok masyarakat biasa atau kebanyakan. Mereka biasanya bekerja sebagai petani, nelayan, atau pengrajin. Lapisan sosial menengah atau ponggaba meliputi para pegawai yang bekerja sebagai birokrat mulai dari tingkat bawah hingga tinggi. Lapisan paling atas atau parjaji adalah para bangsawan baik yang merupakan keturunan raja maupun keturunan orang-orang yang diberi penghargaan oleh pemerintah kolonial.

Selain itu, juga terdapat pelapisan sosial masyrakat Madura menurut dimensi agama yang terbagi menjadi dua lapisan yaitu santree dan bene santre. Kelompok santri dibedakan menjadi tiga tingkatan, Kyai merupakan kelompok masyarakat yang berada pada lapisan atas, bindara dianggap sebagai kelompok masyarakat menegah dan santri sebagai kelompok masyarakat pada lapisan terbawah. Pada wilayah pedesaan Madura, pelapisan sosial berdasarkan dimensi agama lebih diutamakan sehingga seorang Kyai yang bertugas sebaga guru akan lebih didengar dan ditaati perintahnya dan nasihatnya dibandingkan dengan pengusa daerah.

\section{Stratifikasi Sosial sebagai warisan budaya yang membentuk Pola Permukiman}

Permukiman masyarakat Madura selain dipengaruhi oleh lapisan sosial dalam masyarakat, permukiman tradisional Madura juga dipengaruhi oleh mata pencaharian penduduknya yang sebagian besar adalah adalah petani lahan kering sehingga bentuk pola permukiman masyarakatnya mengelompok namun berpencar. Setiap keluarga yang memeiliki hubungan kekerabatan cenderung hidup berkelompok namun terpisahkan oleh lahan pertanian sehingga terlihat berpencar.

Kedudukan seorang Kyai sebagai guru serta panutan dalam masyarakat sehingga kepercayaan masyarakat Madura akan musibah yang terjadi jika melawan atau bertentangan dengan ajaran Kyai menjadikan masjid dan pesantren sebagai pusat pelayanan dan aktivitas sosial masyarakat. Letak masjid dan pondok pesantren ini pada umumnya berada pada jalur sirkulasi primer.

Menurut dimensi kepercayaan masyarakat Madura, ruang permukiman masyarakat Madura terbagi atas dua ruang, yaitu ruang profan dan ruang sakral. 


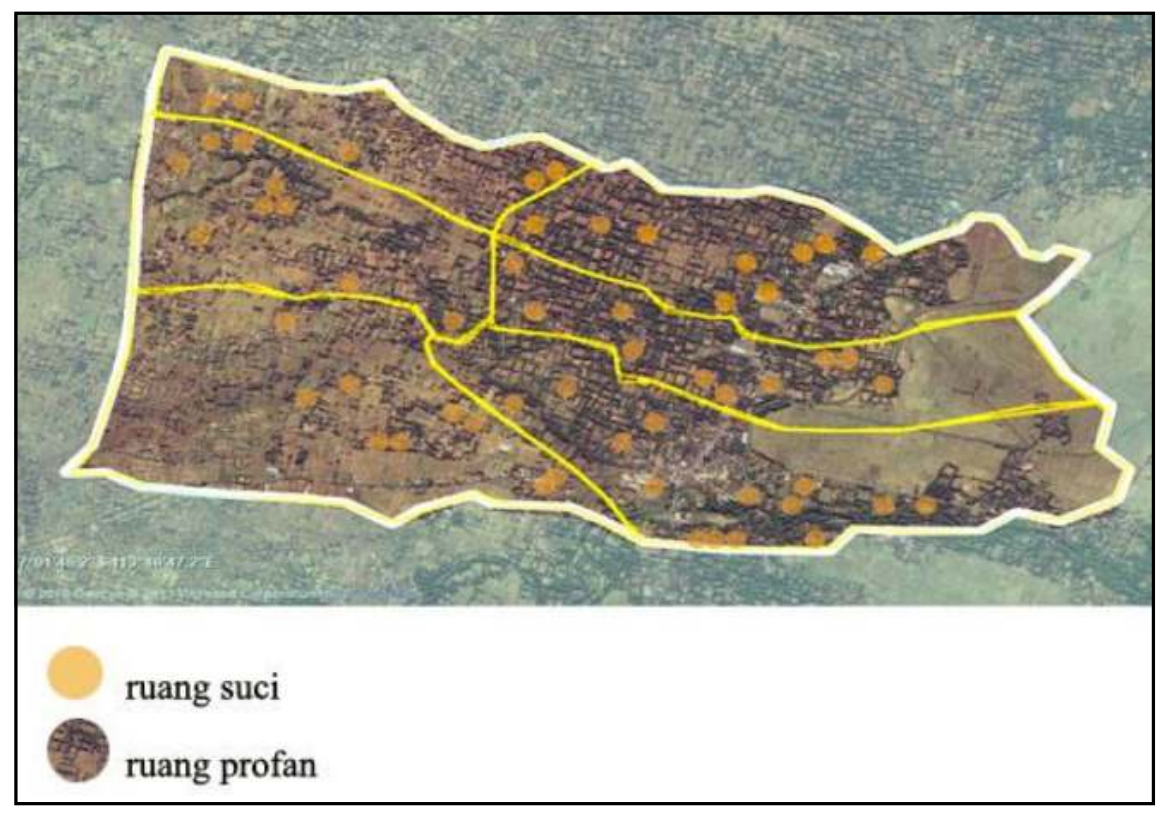

Gambar 8. Tata Ruang menurut Kepercayaan

Sumber ; Maningtyas dkk, 2013

Ruang profan sebagai ruang yang bersifat duniawi sehingga aktivitas dilakukan oleh masyarakat Madura pada ruang tersebut ialah aktivitas sosial yang berkaitan dengan pemenuhan kebeutuhan ekonomi dan hubungan dengan sesame manusia. Sedangkan ruang sakral sebagai ruang yang bersifat suci atau spiritual sehingga aktivitas yang dilakukan oleh masyarakat Madura pada ruang skaral ialah aktivitas bersifat keagamaan dan pelaksanaan dengan kepercayaan yang termasuk didalamnya ialah masjid, rumah dan pemakaman. Sedangkan ruang profan adalah lahan pertanian.

Ruang perumukiman masyarakat Madura terbentuk oleh budaya masyarakat yang memiliki keterkaitan yang erat dengan sistem kepercayaan masyarakat dan kekerabatan masyarakat. Pelapisan sosial yang menurut dimensi agama yang membagi masyarakat kedalam tiga kelompok kyai, santre dan bene santri. Kyai sebagai golongan tertinggi memegang peranan penting dalam masyarakat yaitu sebagai guru yang memberikan ilmu pengetahuan, ilmu agama dan teladan bagi masyarakat sehingga Kyai sangat dihormati. Hal ini yang menjadikan permukiman golongan kyai merupakan pusat aktivitas masyrakat yang berkaitan dengan proses belajar. 


\section{Perbandingan Studi Kasus}

Berdasarkan penjelasan tersebut berikut adalah temuan berdasarkan studi kasusu yang dijabarkan:

\section{Tabel 1 Perbandingan Studi Kasus Pengaruh Stratifikasi Sosial terhadap Pembentukan Pola Permukiman}

\begin{tabular}{|c|c|c|c|c|}
\hline \multirow[b]{2}{*}{ No. } & \multirow[b]{2}{*}{ Sasaran } & \multicolumn{3}{|c|}{ Pengaruh Stratifikasi Sosial Terhadap Pola Permukiman Masyarakat } \\
\hline & & $\begin{array}{c}\text { Pembentukan Pola Permukiman } \\
\text { Kerajaan Pajang sampai dengan } \\
\text { Surakarta }\end{array}$ & $\begin{array}{c}\text { Pembentukan Pola Permukiman } \\
\text { Kota Karangasem }\end{array}$ & $\begin{array}{c}\text { Pembentukan Pola Permukiman } \\
\text { Madura }\end{array}$ \\
\hline 1. & $\begin{array}{l}\text { Elemen pembentuk } \\
\text { stratifikasi sosial sebagai } \\
\text { salah satu warisan budaya }\end{array}$ & $\begin{array}{l}\text { Stratifikasi sosial atau lapisan sosial } \\
\text { yang ada pada masa Kerajaan Pajang } \\
\text { sampai dengan Surakarta terbagi } \\
\text { menjadi } 4 \text { lapisan masyarakat yang } \\
\text { tertinggi sampai dengan yang terendah } \\
\text { yaitu raja, bangsawan, abdi dalem dan } \\
\text { masyarakat biasa. } \\
\text { Lapisan sosial pada masa kerajaan } \\
\text { Pajang sampai dengan Surakarta sangat } \\
\text { dipengaruhi oleh faktor keturunan yang } \\
\text { artinya status atau kelas sosial } \\
\text { seseorang dapat ditirunkan secara } \\
\text { langsung sebaga keturunan dari } \\
\text { seseorang. Seorang raja yang } \\
\text { mempunyai seorang anak, maka secara } \\
\text { otomatis anak tersebut akan menjadi } \\
\text { keluarga raja dan berada pada lapisan } \\
\text { sosial tertingggi. } \\
\text { Selain itu, lapisan sosial pada masa itu } \\
\text { juga dapat dipengaruhi oleh profesi. } \\
\text { Abdi dalem, sebagai pekerja kerajaan } \\
\text { merupakan sebuah profesi yang tidak } \\
\text { diturunkan pada keturunannya. } \\
\text { Seseorang dapat menjadi seorang abdi } \\
\text { dalem berdasarkan gerakan hati } \\
\text { sebagai bentuk pengabdian kepada } \\
\text { kerajaan yang dipercayai merupakan } \\
\text { pusat dari kehidupan. }\end{array}$ & $\begin{array}{l}\text { Stratifikasi sosial atau lapisan sosial } \\
\text { yang ada pada Kota Karangasem } \\
\text { sebagai salah satu kota peninggalan } \\
\text { Kerajaan Hindu di Bali terbagi } \\
\text { menjadi } 4 \text { lapisan masyarakat yaitu } \\
\text { brahmana, ksatrya, wesya dan sudra } \\
\text { yang disebut sebagai catur wangsa. } \\
\text { Merupakan pembagian masyarakat } \\
\text { menjadi empat golongan berdasarkan } \\
\text { konsep jati yaitu sesuai dengan garis } \\
\text { keturunan atau kelahiran, kewajiban } \\
\text { bakat atau pekerjaan. }\end{array}$ & $\begin{array}{l}\text { Stratifikasi sosial atau lapisan sosial } \\
\text { yang terdapat di Madura terbagi } \\
\text { menjadi } 3 \text { lapisan masyarakat yaitu } \\
\text { Kyai, Santree dan Bane santre. } \\
\text { Pembagian masyarakat kedalam tiga } \\
\text { lapisan tersebut berdasarkan } \\
\text { kepercayaan masyarakat Madura yang } \\
\text { kental terhadap agama yang dianut } \\
\text { yaitu agama Islam. }\end{array}$ \\
\hline
\end{tabular}

Boby Rahman, Ega Selviyanti I 209 
Jurnal Planologi Vol. 15, No. 2, Oktober 2018

Available : http://jurnal.unissula.ac.id/index.php/psa

\begin{tabular}{|c|c|c|c|c|}
\hline \multirow[b]{2}{*}{ No. } & \multirow[b]{2}{*}{ Sasaran } & \multicolumn{3}{|c|}{ Pengaruh Stratifikasi Sosial Terhadap Pola Permukiman Masyarakat } \\
\hline & & $\begin{array}{c}\text { Pembentukan Pola Permukiman } \\
\text { Kerajaan Pajang sampai dengan } \\
\text { Surakarta }\end{array}$ & $\begin{array}{c}\text { Pembentukan Pola Permukiman } \\
\text { Kota Karangasem }\end{array}$ & $\begin{array}{c}\text { Pembentukan Pola Permukiman } \\
\text { Madura }\end{array}$ \\
\hline 2. & $\begin{array}{lr}\text { Stratifikasi } & \text { sosial sebagai } \\
\text { pembentuk } & \text { permukiman } \\
\text { masyarakat } & \end{array}$ & $\begin{array}{l}\text { Stratifikasi sosial yang mempengaruhi } \\
\text { permukiman masyarakat menjadikan } \\
\text { bentuk pola atau tatanan permukiman } \\
\text { masyarakat pada zaman kerajaan } \\
\text { Pajang sampai dengan Surakarta } \\
\text { sebagai berikut: } \\
\text { Pola permukiman masyarakat yang } \\
\text { memusat dan membentuk lingkaran } \\
\text { imajiner dengan keraton sebagai pusat } \\
\text { dari permukiman yang merupakan } \\
\text { tempat tinggal raja dan keluarganya } \\
\text { yang menduduki tingkatan lapisan } \\
\text { tertinggi. Kemudian bangsawan dan } \\
\text { abdi dalam yang menepati lapisan } \\
\text { kedua serta masyarakat biasa yang } \\
\text { menempati lapisan terakhir }\end{array}$ & 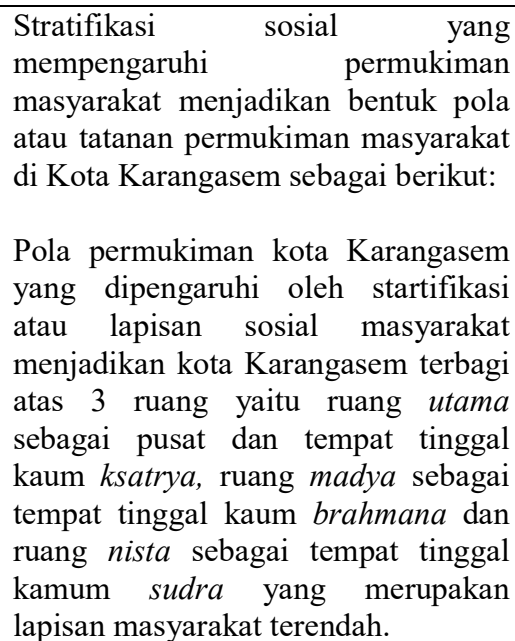 & $\begin{array}{l}\text { Pola permukiman Madura yang } \\
\text { dipengaruhi oleh stratifikas sosial } \\
\text { dalam masyarakat menjadikan pola } \\
\text { permukiman yang memusat dengan } \\
\text { pusat lingkungan adalah masjid atau } \\
\text { pondok. Hal ini dikarenakan akan } \\
\text { kepercayaan dan Kyai sebagai lapisan } \\
\text { masyarakat tertinggi sebagai pusat } \\
\text { permukiman. }\end{array}$ \\
\hline
\end{tabular}

Sumber : Hasil Analisis, 2017

Boby Rahman, Ega Selviyanti I 210

Studi Literatur : Peran Stratifikasi Sosial Masyarakat ... 
Jurnal Planologi Vol. 15, No. 2, April 2018

Available : http://jurnal.unissula.ac.id/index.php/psa

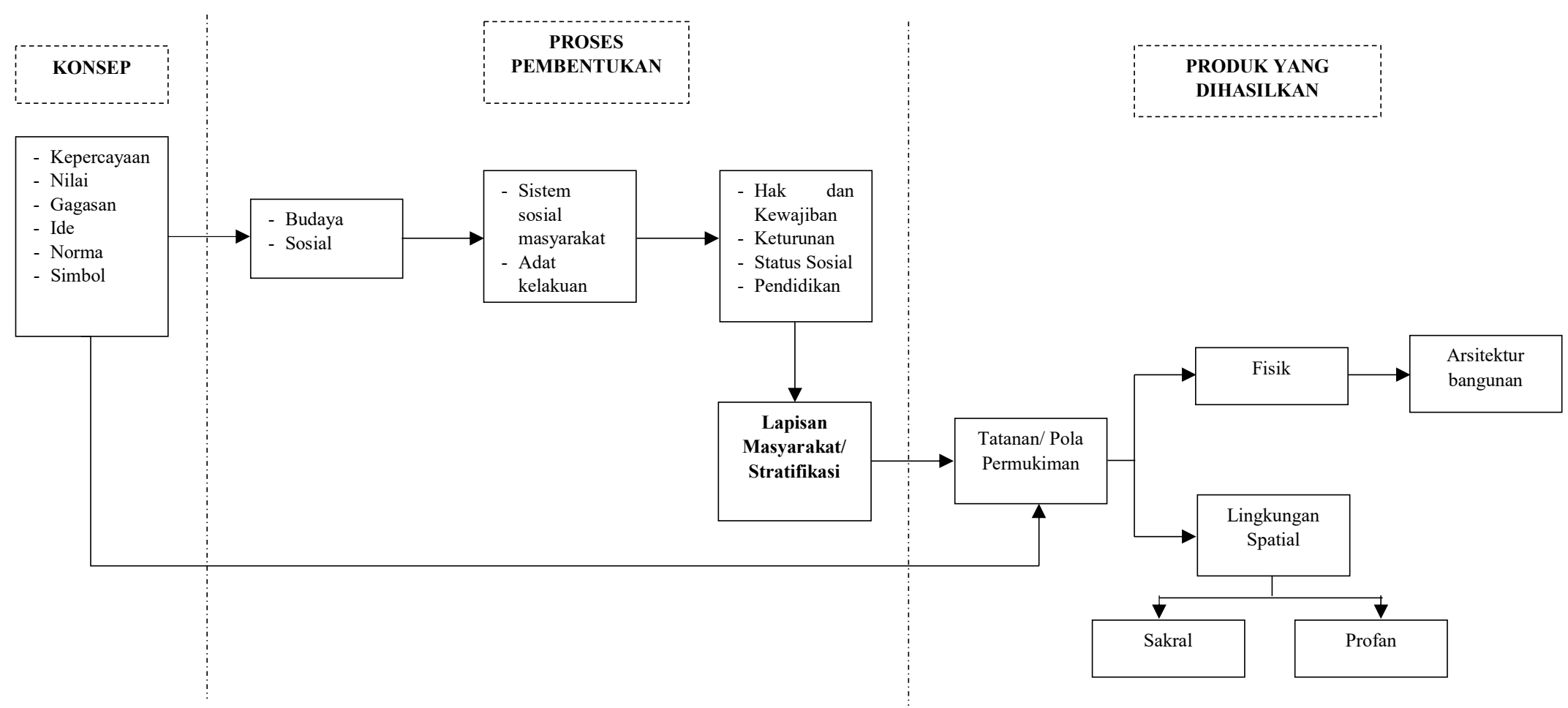

Gambar 9. Analisis Peran Stratifikasi Sosial terhadap Pembentukan Pola Permukiman

Sumber : Hasil Analisis Penulis, 2017 
Stratifikasi sosial atau lapisan sosial merupakan salah satu hasil dari kebudayaan yang berkembang dan dipertahankan oleh beberapa kelompok masyarakat tertentu. Pembentukan permukiman masyarakat oleh stratifikasi atau lapisan masyarakat dapat dijabarkan kedalam tiga proses yaitu konsep, proses dan produk. Konsep pada pembentukan permukiman yang dipegaruhi oleh stratifikasi sosial merupakan landasan dari terbentuknya stratifikasi sosial dalam masyarakat seperti yang dijelaskan oleh Koentjaraningrat bahwa kebudayaan tersusun atas unsur keagamaan atau kepercayaan, ide, gagasan, norma dan simbol. Unsur-unsur tersebut kebudayaan membentuk sosial budaya masyarakat yang menjadi proses terbentuknya lapisan masyarakat. Yaitu sosial masyarakat menciptakan sistem sosial dalam masyarakat dan budaya menciptakan adat kelakuan masyarakat.

Terbentuknya sistem sosial dalam masyarakat, secara langsung akan membedakan hak dan kewajiwan serta kewajiban dan tanggung jawab dalam masyarakat yang dijelaskan oleh Zainuddin Ali (2007) yaitu akan terdapat letak tidak seimbangan terhadap dua hal tersebut yang berpengaruh kepada manusia sebagai anggota masyarakat. Perbedaan dan ketidak seimbangan antara hak dan kewajiban serta kewajiban dan tanggung jawab tersebut yang kemudian membentuk lapisan-lapisan dalam masyarakat. Masyarakat yang berada pada lapisan atas cenderung memiliki tugas dan tanggung jawab serta hak dan kewajiban dalam mengurus wilayah, pemerintahan dan masyarakat secara menyeluruh hal ini dapat dilihat pada ke tiga studi kasus. Di Bali misalnya brahmana sebagai kelompok masyarakat yang berada pada lapisan atas berkewajiban mengembangkan ilmu dan pengetahuan dan ksatria yang memiliki kewajiban dalam menjalankan pemerintahan dan militer.

Perbedaan tersebut kemudian membentuk tatanan permukiman masyarakat. Masyarakat dengan kedudukan tertinggi atau berada pada lapisan inti/pusat dalam masyarakat akan membentuk tatanan permukiman yang tidak dapat dimasuki oleh semua lapisan masyarakat yang menjadi ruang sakral dalam tatanan permukiman. Sedangkan masyarakat yang berada pada lapisan yang lebih rendah juga akan membentuk ruang kegiatannya yaitu ruang profan yang cenderung dapat dimasuki oleh semua lapisan dalam masyarakat. Hal ini terlihat jelas dalam pembentukan struktur kota Kerajaan Mataram Islam sampai dengan Surakarta yang menjelaskan secara jelas bahwa lapisan masyarakat membentuk tatanan permukiman masyarakat secara bertingkat dengan dalem yang merupakan tempat tinggal raja dan keluarganya sebagai inti dari tatanan permukiman. 


\section{KESIMPULAN DAN SARAN}

\section{Kesimpulan}

Implikasinya, banyak permukiman yang terpengaruh oleh nilai dan perilaku budaya dalam kehidupan bermasyarakat sehingga membentuk lokasi tertentu dan menjadi wujud ruang yang membentuk pola permukiman yang identik dengan sosial budaya masyarakat itu sendiri.

Sehingga berdasarkan pembahasan dan hasil kajian tersebut, dapat diambil beberapa kesimpulan sebagai berikut:

1. Elemen-elemen pembentuk stratifikasi atau lapisan sosial dalam masyarakat berupa keturunan sebagai elemen yang paling berpengaruh terhadap kelas sosial masyarakat, kemudian terdapat elemen profesi dan bakat.

2. Stratifikasi sosial sebagai salah satu warisan budaya masyarakat berpengaruh terhadap pembentukan permukiman masyarakat. Unsur-unsur kebudayaan yang kuat dan tradisi masyarakat menyusun ruang permukiman kedalam konsepsi lapisan ruang sakral dan ruang profan.

3. Pola permukiman yang terbentuk atas pengaruh startifikasi sosial atau lapisan sosial dalam masyarakat cenderung memusat dan membentuk ruang-ruang imajiner berdasarkan kelas atau status sosial dalam masyarakat.

4. Masyarakat dengan tingkat atau kelas sosial tertinggi berada pada pusat permukiman masyarakat dan masyarakat dengan lapisan berikutnya mengikuti tingkat tertinggi tersebut.

\section{Saran}

Dalam pengembangan kawasan, tata ruang sebaiknya memperhatikan warisan budaya sebagai karakter suatu kawasan. Hal ini sangat penting guna arah pengembangan tata ruang yang minim konflik serta tepat sasaran dari aspek ruang budaya (konsepsi lapisan ruang sakral dan ruang profan), sesuai dengan pola pengembangan kebutuhan (ruang-ruang imajiner) dan ruang ekspresi bagi masyarakat. Kekhasan yang muncul dari lapisan stratifikasi sosial, dapat memberikan nilai tambah kawasan dan peningkatan ekonomi, hal ini sejalan bila dipadukan dengan aktivitas wisata budaya yang terus berkembang dan semakin diminati. 


\section{DAFTAR PUSTAKA}

Aliyah, I. (2004). Identifikasi Kampung Kemlayan sebagai Kampung Tradisional Jawa di Pusat Kota. Jurnal Teknik. 11 (1), 33 - 40.

Danial, Endang. \& Nanan, Warsiah. (2009). Metode Penulisan Karya Ilmiah. Bandung: Laboraturium Pendidikan Kewarganegaraan

Hardy, I. G. N. W., Setiawan, B., \& Prayitno, B. (2016). Pengaruh Sistem Catur Wangsa terhadap Perwujudan Tata Spasial Kota Peninggalan Kerajaan Hindu di Bali: Kasus Kota Karangasem. Journal of Bali Studies, 6(2), 79-96.

Junianto. (2016). Konsep Mancapat-Mancalima Dalam Struktur Kota Kerajaan Mataram Islam Periode Kerajaan Pajang Sampai Dengan Surakarta. Dalam Seminar Nasional Space \#3 Membingkai Multikultural dan Kearifan Lokal Melalui Perencanaan Wilayah dan Kota. 3 (1), 234-253.

Karmadi, A. D. (2007). Budaya Lokal Sebagai Warisan Budaya dan Upaya Pelestariannya. Makalah disampaikan pada Dialog Budaya Daerah Jawa Tengah. Semarang : Balai Pelestarian Sejarah dan Nilai Tradisional Yogyakarta dan Dinas Pendidikan dan Kebudayaan Propinsi Jawa Tengah.

Koentjaraningrat. (1992). Kebudayaan Mentalitas dan pembangunan. Jakarta: PT. Gramedia Pustaka Utama

Kartiningrum, Eka, Diah. (2015). Panduan Penyusunan Studi Literatur. Mojokerto : Politeknik Kesehatan Majapahit

Maningtyas, R., T. (2013). Kajian Desain Lanskap ermukiman Tradisional Madura. Skripsi. Bogor : Sekolah Institiut Pertanian Bogor

Murtoyoso, S. (1993) Sejarah Arsitektur Kota di Kawasan Budaya Pesisir. Surabaya: Seminar Pelestarian Arsitektur Kota

Pusparinda, Laela. \& Santoso, R., I., B. (2016). Studi Literatur Perencanaan Floating Treatment Wetland di Indonesia. Jurnal Teknik ITS. 5 (2) A475-1-A475

Rapoport, Amos. (1980). Pengantar Arsitektur. Jakarta. Penerbit Erlangga

Rifa'i, Mien Ahmad. (2007). Manusia Madura: Pembawaan, Perilaku, Etos Kerja, Penampilan dan Pandangan Hidupnya Seperti Dicitrakan Peribahasanya. Yogyakarta: Pilar Media Santoso, J. (1984). Konsep Struktur dan Bentuk Kota Jawa s/d Abad XVII. Bandung. Institut Teknologi Bandung 
Wiyata, Latief. (2002). Carok Konflik Kekerasan dan Harga Diri Orang Madura. Yogyakarta: LKiS.

Ali, Z. (2007). Sosiologi Hukum. Jakarta: Sinar Grafika. 